\title{
$7 \quad$ Engaging the public for citizen energy production in Norway
}

\author{
Energy narratives, opportunities and \\ barriers for an inclusive energy transition
}

\author{
Karina Standal and Mariëlle Feenstra
}

\section{Introduction}

In recent years there has been an emerging policy attention to how people can engage with energy production, either as prosumers with their own energy production system at home or through participation in community energy systems. The recast Renewable Energy Directive (RED II) is one of the latest examples, which include requirements for EU Member States to provide enabling frameworks for renewable community energy empowering them to participate in the energy market. Further, several countries have provided economic incentives (e.g., Feed-In Tariffs, subsidies and tax schemes) to increase the attractiveness for citizen energy production in the form of prosumerism where decentralised energy production from households (or business sector) are integrated into the grid supply (Standal et al., 2021; Inderberg et al., 2018). Furthermore, the current technological innovation and opportunities for decentralised renewable systems for production and energy storage enable the rise of new collective forms of energy citizenship. These distributed energy systems are viewed as a potential grassroot transformation of national electricity systems (Seyfang et al., 2014; SchleicherTappeser, 2012). In this chapter we focus on the linkages between dominating energy narratives and on injustices in the energy system in terms of social and gender difference in engaging citizens in energy producers at household and community level. We place our observations in the context of Norway.

The backdrop of policies and incentives for engaging citizens to become energy producers is the need to accelerate the low-carbon energy transition. Citizens who engage in energy production and storage may be important components in electricity systems as future electrification of society puts new demand on energy production, supply and flexibility. Community energy has also been identified as an important step towards increasing social acceptance of renewable energy resources as it enables trust and influence over processes (Linnerud et al., 2019; Linnerud et al., 2018). RED II's stringent definitions of renewable energy communities, including open democratic participation, proximity, and primary purpose to be environmental, economic or social community benefits rather than financial profits, align well with increasing social acceptance of renewable energy technologies and bottom-up transformation. Promoting citizen energy production 
constitutes a blurring of the consumer-producer distinction and attributed benefits and responsibilities. Achieving a transition that enables the rise of new collective forms of citizen energy production also includes a shift of power within the established electricity system. In this context it is problematic that, as found in research in the Northern countries, energy policies are incorrectly considered neutral by policy makers, neglecting the differential impacts these policies have on socio-economic and cultural groups, including different genders (Clancy and Feenstra, 2019; Standal, Winther and Danielsen, 2018). This policy gap suggests that it is not sufficient to investigate "first-order" questions of whether citizens have formal rights and access to needed resources to become energy producers (see Fraser et al., 2004). To ensure a just energy transition that provides the trust and attractiveness for citizen participation, which is needed for making significant change, we need to also engage with dimensions of gender and other intersecting identities that provide more subtle, but efficient mechanisms of exclusion.

As outlined above, scaling up the low-carbon energy transition with citizen energy production forwards an urgent need to recognise how people can equitably engage in the energy transformation. A sustainable energy system needs to address how to satisfy human needs, ensure social justice and respect environmental limits (Holden, Linnerud and Rygg, 2021). The present research literature has mainly put an emphasis on technical and managerial issues of decentralised energy systems and integration into the centralised grid supply (Olivier, Marulli and Fonteneau, 2017; Parag and Sovacool, 2016), whereas some literature provides insights in motivations for citizens to engage in energy production on household or community level (Inderberg et al., 2020; Palm, 2018; Winther, Westskog and Sæle, 2018; Olkkonen and Grönberg, 2017; Juntunen, 2014) or explored whether citizen-driven distributed systems impact social acceptability (Leiren et al., 2020; Linnerud et al., 2019) and even fewer have explored gender dimensions (Allen et al., 2019; Standal, Talevi and Westskog, 2019; Fraune, 2015) or different actors roles and interactions (Inderberg et al., 2020; Skjølsvold et al., 2018).

As a response to this knowledge gap, we explore from a justice perspective how Norwegian energy narratives reinforce and produce structures of gender and intersectional social differentiation hindering citizen energy production from becoming more mainstream. Norway stands out as an interesting case to investigate as the government and the electricity sector has expressed high ambitions for electrification of society as a main factor in the low-carbon energy transition. Further, Norway seemingly has an abundance of renewable energy resources from hydro- and wind power, making such ambitions technically feasible. Furthermore, the general population in Norway has high material well-being and a high level of gender equality. Through a "narrative approach" and justice theory lens, we explore how institutions (in broad terms) generate and reflect citizen energy production in the general discourse and in regulations and incentives. In this process, we draw on policy and media material, and in-depth interviews with prosumers and representatives from the electricity sector from new and previous research conducted by the authors. 
The chapter is structured as follows. In the next section, we present and discuss the core concepts of energy justice that we apply as a justice lens in our analysis. In the following section, we discuss the main narratives of the Norwegian electricity system and what actors and perspectives are recognised as legitimate in the low-carbon energy transition. We pay particular attention to regulations and policies relevant to prosumerism and renewable energy communities. The next section explores the "citizen" narrative based on the lived realities of prosumers experience in Norway (Standal et al., 2021; Standal, Talevi and Westskog, 2019; Standal et al., 2018). We then proceed to discuss how these narratives may be understood in terms of access to types of capital and the larger debates of politics of redistribution and politics of recognition of different groups in society. In our concluding section, we discuss how knowledge on how people can engage in energy production needs to encompass broader than access to resources and formal rights to scale up an energy transition for the people and with the people.

\section{Citizen energy production and the energy justice lens}

The quest for a just energy transition is rooted in the energy justice debate. Energy justice is an emerging framework in energy social science that has developed to analyse energy transition and energy policy. Three main tenets of energy justice are articulated as distributional, recognitional and procedural justice (Sovacool and Dworkin, 2015). Energy justice has three functions: (i) conceptual, (ii) analytical framework for energy policy feeding into the use of energy justice and (iii) a decision-making tool to enable a move towards a just energy transition (Sovacool and Dworkin, 2015). The aim of energy justice is to contribute to a just energy transition with a just distribution of rights, recognition of needs and just decision-making within the energy system (Sovacool et al., 2016).

The energy transition takes place within a specific governance context, which has implications for energy justice. The key policy goal of energy transition is decarbonisation: moving from fossil fuels to renewable energy sources and increasing energy efficiency, a goal agreed collectively by EU countries and beyond. The process of decarbonisation requires to pay close attention to distributional justice: in order to prevent unequal distribution of risks, cost-benefit and rights, a key aspect needing attention is monitoring and measuring energy poverty. The second point of attention is an expectation that decentralised self-generation will play a greater role in meeting decarbonisation targets. It is expected that the energy transition will include a policy shift from supply-oriented towards demand-driven energy policy. The EU, for example, envisions an internal energy market where citizens take ownership of the energy transition, benefit from new technologies to reduce their bills and participate actively in the market. In short, it places citizens central to empower households to self-generate, sell or store necessary supplies, participate in citizen energy communities or enter into dynamic price contracts which will allow (and require them) to respond to peaks in (cheaper) renewable energy at any time of the day (Diestelmeier and Hesselman, 2018). This will be made possible by new (smart) technologies and 
demand-driven policies. With this shift, it thus becomes important to ask who will become the energy providers, who will (chiefly) remain end-users and who will be able to navigate all these new options and invest in relevant technologies (e.g., solar panels, batteries, smart home systems etc.). These questions are also key in considering recognition justice: who may face specific challenges in participating and reaping benefits of the transition fully and how to ensure that a range of interests and needs are represented in decision-making and policy action (McCauley et al., 2013).

This goal of decarbonisation is set within a larger shift in energy systems. A governance shift in energy systems from governments acting as public service providers, in pre-liberalised areas, to governments becoming regulators as markets opened up, to governments becoming facilitators of energy transition and various partnerships of corporate, government and civil society actors. Energy projects are increasingly characterised as public-private-partnerships collaborating in a triple-helix (corporate, government and society). In this context, more actors are entering the energy market pushing the government into the role of broker between the energy sector and consumers. This governance shift challenges procedural justice in the energy sector because with an increase of actors and entanglement of roles and mandates, energy governance becomes less transparent and fair procedures could be at jeopardy (Jenkins et al., 2016). The possibility for procedural justice in governance of the energy transition relies on the governance structure within a country being open to collaborative working strengthened by the legal frameworks and institutions enforcing and implementing such processes. Furthermore, the existence of a well-organised and collaborative civil society and space for stakeholder participation in the energy system relies on recognition of the needs and rights of actors within that system.

The above articulation of the policy and governance context of the energy transition in light of the energy justice framework suggests that several justice issues need close attention here. First, from a perspective of recognition and participatory justice, citizens are vital to the process of energy governance, given the potential for that process to have positive or negative consequences for them. The energy transition might open new ways for citizens to participate in energy governance. This might also be a pathway for marginalised groups to shape energy policy and secure better outcomes (Feenstra and Özerol, 2021; Standal and Feenstra, 2021). Secondly, while placing the consumer as central in policymaking is important, it also risks suggesting that responsibility for the transition is transferred from government to individuals. The consumer is often blackboxed in policy (Ellegård and Palm, 2015), and there are risks associated with the assumption that the end-user derives from a homogenous entity that responds equally to policies and has the same recognition and ability for participation, decision-making and benefits to participate in the energy system and is able to claim the role of an actor in decision-making processes.

With regards to people's agency to take on new roles in the energy transition, we draw on concepts of material and immaterial capital such as financial resources (economic capital), social networks that provide benefits and security 
(social capital), and skills and knowledge (human capital). We combine this with Bourdieu's (1986) concept of symbolic capital, which means that resources accessible to an individual are based on the recognition the person holds within a socio-cultural context. The power derived from symbolic capital is usually hidden as it is obscured in practices portrayed as natural; produced and legitimised through history or religion (Bourdieu, 1986; see also Ahlborg, 2017). We find symbolic capital relevant to understanding gendered roles and work divisions that are often internalised as socio-cultural norms where activities tied to the "masculine" are assigned a higher economic and social value than "feminine" ones (e.g., domestic work, informal and unskilled labour) existing beyond discourse or argumentation. This gendered division of labour has led to a skewed distribution of resources between men and women and lack of recognition of women as stakeholders in many contexts, including energy-related (Lieu et al., 2020; Standal, Winther and Danielsen, 2018). As a result, women have been disadvantaged in terms of economic, social and symbolic capital (Standal, Winther and Danielsen, 2018).

\section{Methods}

In this chapter, we draw on empirical material from previous studies conducted by the authors. In-depth interviews with prosumers in Norway (Standal, Talevi and Westskog, 2019; Standal et al., 2018) and interviews with representatives from the Norwegian energy sector (Standal et al., 2021) are combined with a mapping of media, advertisement, policy and regulatory framework conditions on household and community energy prosuming in Norway. We analyse this material using a "narrative approach" and justice theory to understand how institutions (in broad terms) generate and reflect citizen energy production in the general discourse and framework conditions and the impact for engaging the Norwegian public towards citizen energy production. The energy transition is an emerging field in policy, practice and research with new actors bringing different concepts in their narratives. The understanding and knowledge on energy transition are growing bringing new insights into perspectives of energy actors. Drawing on several studies conducted over time provides the benefit of a holistic and longitudinal overview that capture changes in discourses over time in the public and policy debate on energy transitions. It also provides opportunities to link user perspectives and practices with policy and energy system perspectives. An overview of the data material is listed in Table 7.1.

\section{The dominating system narrative: the blessings of natural resources and cost-efficiency}

The dominating energy narratives in Norway focus on the natural resources and cost-efficiency of the system (Standal et al., 2021), resulting in a resounding absence of gender perspectives and social inequality which is observed in many European countries with a neo-liberal background (Feenstra and Clancy, 2020). 
Table 7.1 Interviewees information

\begin{tabular}{lll}
\hline Informant ID & Gender & Position/Occupation \\
\hline S1 & M & CEO small-scale RES systems company \\
S2 & M & Financial director small-scale RES power production company \\
S3 & M & CEO Member association for small-scale RES energy production \\
S4 & F & CEO grid company \\
S5 & F & Employee grid company \\
S6 & F & Employee grid company \\
S7 & M & Employee grid company \\
H1 & F & Homemaker \\
& M & Energy sector \\
H2 & F & Care sector \\
& M & Consultancy/energy sector \\
H3 & F & Educational sector \\
& M & Energy sector \\
H4 & F & Artist \\
& M & Farmer \\
H5 & F & Farmer/educational sector \\
& M & Farmer \\
H6 & M & Environmental NGO \\
H7 & F & Educational sector \\
& M & Educational sector \\
H8 & F & Energy sector \\
H9 & F & Retired (prev. educational sector) \\
& M & Energy sector \\
H10 & F & Nature conservation \\
H11 & M & Energy sector \\
H12 & F & Energy sector \\
H13 & F & Energy sector \\
& M & Retired (prev. librarian) \\
H14 & F & Health sector \\
& M & Sales \\
& M & ICT \\
\hline & & \\
& & \\
& &
\end{tabular}

Northern European countries have a long-standing tradition of a free-market economy and non-discrimination rooted in their law, leading to the assumption that formalisation of equal rights will effectively ensure equal outcomes, overlooking social differentiation. From a policy perspective, energy is often attributed to national security and positioned in the technical and economic domain and as a consequence, energy policy has persistently been viewed as gender-neutral domain. However, research identified energy as a "male-domain," meaning that energy policy decision-making and energy-related employment, and even in some cases access to energy, are unequally distributed among men and women to (Feenstra and Clancy, 2020; Lieu et al., 2020; Standal, Winther and Danielsen, 2018).

The main imagery of the Norwegian electricity production and supply centres around Norway's abundance of natural energy resources, hydro and wind, and how the Norwegian electricity system managed in a rational economic way, which provides Norwegian citizens with environmentally friendly and reliable 
electricity at a fair price. Norway as a nation is almost completely self-sufficient in renewable electricity supply. Hydropower is the main energy resource, both in numbers and historically, and constituted $92 \%$ of the energy mix in 2020 (Statistics Norway, 2021a). A significant part of the hydropower is sourced from small-scale plants owned by farmers or landowners with waterfall rights (Standal et al., 2021). From 2016 the Norwegian government signalled onshore wind power as the "new big thing" (GoN, 2016), and the wind power share has gradually increased to about $6.4 \%$ alongside a small share of thermal power of $1 \%$ (Statistics Norway, 2021a).

The main foundation of the Norwegian Energy Act is to ensure that production, transformation, transmission, sale, distribution and use of energy takes place in a socially rational way. Norway was early in liberalising the electricity sector in 1991 and joined the power exchange marked Nord Pool AS in 1996. Norway has an open electricity market, integrated with the other Nordic countries. Norway often imports power when the price is low at night-time while exporting at daytime when the price is higher (Linnerud et al., 2018). Despite liberalisation, the grid companies are under regulated monopoly and frequently owned by municipalities. The idea of the electricity system as cost-efficient is upheld by the fact that the delivery reliability is high, despite challenging climate conditions, especially during extreme weather events. However such events are unevenly distributed geographically, and Norway has "cold spots" in the electricity network (Wethal, 2020). Though the fluctuations of the electricity prices are duly noted in media in the winter season (freezing of waters and higher demand lead to increased prices), the trust in the electricity system is high, and electricity is a "low interest product" among consumers (Interviews S4-S7). As a continuation of the dominating Norwegian energy narrative, the government has put an emphasis on the electrification of society, particularly the transport sector, in the low-carbon energy transition in Norway (Holden et al., 2020; GoN, 2016).

Social dimension aspects only figure in the dominating narratives in terms of distribution of the wealth deriving from Norwegian energy resources. A striking feature of the Norwegian electricity sector is that the majority of natural energy resources and the supply chain of grid companies are under public sector ownership. According to the Norwegian Water Resources and Energy Directorate (NVE) $90 \%$ of the hydropower plants are owned by municipalities and the state (NVE, 2021). A large part of the income of production thus benefits the citizens (Breitschopf, Grave and Bourgault, 2016). This is also highly reflected in the dominating energy narrative where energy resources (hydro, wind and oil) are understood as commons or shared resource. Therefore, oil and hydropower production are subjected to a ground rent (Standal et al., 2021). Norway's ambitions for a low-carbon society relate to the electricity sector almost exclusively in terms of the services it may provide (providing input for electrification of transport) and not the substance of electricity production. Technologies such as solar photovoltaics (PV) and bioenergy, as well as decentralised energy solutions have a minimal role in the energy transition. 


\section{Karina Standal and Mariëlle Feenstra}

In recent years, a highly visible counter-narrative to the hegemonic presentation of Norway's energy system as environmentally friendly and fair has emerged in the increasing opposition to onshore wind power. Environmental degradation of pristine nature with consequences for wildlife, landscape and humans, as well as lack of acknowledgement for the Sami indigenous population rights (in relation to reindeer herding) and lack of trust in the processes of giving concessions has been raised in the opposition (Standal et al., 2021; Leiren et al., 2020; Linnerud et al., 2018). The resistance of the Sami population has included a strong criticism of how national policies overlook issues of local resource management and indigenous livelihoods, of which gender roles often are an important dimension. The value of land has different meanings to different stakeholders, reducing the recognition of those with less power. Further, the interest and needs concerning different social roles (care work in the household) and cultural aspects (Sami livelihood as a bearer of tradition) are not seen as relevant. This has also been found in other studies (e.g., Lieu et al., 2020). Today all wind concessions are halted, pending new legislation and procedures. The arguments above are further underscored by the common claim that onshore wind power development depletes Norway's ownership and control to parts of its natural energy resources due to foreign investment and ownership (Jensen and Aamodt, 2020). Compared to hydropower only $33 \%$ of the onshore wind power plants in Norway are under public sector ownership, while $62 \%$ are owned by foreign investors (NVE, 2021). In addition, given Norway's self-sufficiency with hydropower, government support for onshore wind power is considered to be subsidisation of other countries in Europe for them to reach their RES targets (Jensen and Aamodt, 2020). As with wind power, Norway's integration with Europe and development of transmission cables for exporting electricity to Europe is faced with significant opposition (ibid).

As shown above, the dominating Norwegian energy narrative does not highlight aspects of social inclusion and how socio-economic, gender and cultural groups have access to participation and decision-making as well as impacts of the energy transition. As mentioned in the introduction of this section, energy policy in Northern European countries with a strong legacy of neo-liberal policies, are considered to be (gender) neutral and benefitting their citizens equally based on the strong non-discriminatory legal framework (Johnson et al., 2020). As an example, research has found that energy poverty exists in Norway, but the issue is not understood as a problem concerning energy and is assumed to be dealt with under other policies (Bredvold, 2020). This poses a problem for the just transition as dominating narratives impact people's opportunities and impacts on the process. As shown in previous research, this assumption of neutrality is false and, as a consequence, hide existing injustices and inequalities in the energy system (Feenstra and Clancy, 2020; Johnson et al., 2020; Standal, Winther and Danielsen, 2018). In terms of activating the public for citizen energy production, the energy narrative has justified (through national policies) an electricity system dominated by traditional actors and constrained other narratives, which have limited the opportunities for citizen energy production. 


\section{Framework conditions for prosumers and renewable energy communities}

The dominating understanding of Norway's electricity system (environmentally friendly shared resources operated in a cost-efficient and reliable manner) has impacted the framework conditions for citizen actors to engage in the electricity sector as energy producers. Firstly, such framework conditions are not a high policy priority since there is a lack of momentum for change (the electricity supply is already fully self-sufficient in renewable energy) (Jensen and Aamodt, 2020). Further, the lack of focus on social inclusion has enabled policy blindness towards social differentiation (including gender), resulting in "one size fits all" support schemes and regulations (Standal, Talevi and Westskog, 2019). These have consequences for the uptake of renewable energy production in households and communities.

Prosuming constitutes a new frontier in the Norwegian electricity system. Prior to 2010, there were no regulations concerning prosuming in Norway, though some individual customers had informal arrangements with grid companies for integrating their own PV production into the grid supply. In 2010, the Norwegian Water Resources and Energy Directive (NVE) issued light regulations that provided private households with energy production some right as prosumers, but the most influential change was the "plus customer scheme" implemented in 2017 (Inderberg, Tews and Turner, 2018). A "plus customer" is defined as an end-user that consume and produce energy "behind the meter," from which the power put into the grid does not exceed $100 \mathrm{~kW}$ at any time (Standal et al., 2021). Participants of the "plus-customer" scheme may use self-consumed electricity free of charge and are exempt from grid tariffs concerning electricity production and self-consumption. The plus customers can also sell their excess production to an electricity supplier without a trading license. It is also possible to be a prosumer from which the power put into the grid ranges between 100 $\mathrm{kW}$ and $1 \mathrm{GWh}$. Such prosumers are subject to pay a regular tariff and a tariff for feeding in electricity (ibid). This scheme has also been helped by the mandatory roll-out of smart meters in Norwegian households (by 2019), which allows twoways communication on production and consumption with grid operators.

The plus customer scheme has been influential in advancing prosuming among households in Norway, though the number is still much lower than neighbouring countries, Sweden and Denmark (Inderberg et al., 2020). One framework condition barrier discussed in the next section is the related transaction costs for households to engage in prosuming (Standal et al., 2021). The plus customer is responsible for complying with all technical requirements of the installation (often arranged through certified third-party companies). The grid companies are obliged to provide information on needed technical requirements and to facilitate the feed-in of electricity as part of its ordinary services, but there is a variation of practices among the grid companies making this more difficult for the prosumers, especially those that engage local energy communities (Interview S3). Further, the regulation concerning metering is an impediment to establishing 


\section{Karina Standal and Mariëlle Feenstra}

energy communities as it excludes joint production facilities. NVE and the government have signalled that a new regulation is in the process to allow households within the same building to establish joint energy production projects (through virtual metering) and inclusion in the plus customer scheme set to start in 2022 (GoN, 2021). However, this might exclude citizen energy production in sparsely populated areas where community energy could provide local growth and hinder depopulation (Standal et al., 2021). The joint metering regulations make certain exemptions for farmer communities with their own low-voltage grid, and there are a few of them scattered in Norway. As presented above, it requires a degree of skills to familiarise with current regulations and possible support schemes. This threshold is perpetuated by the gender gap in the fields of science, technology, engineering and mathematics (STEM) (Standal and Feenstra, 2021; Fraune, 2015).

Another framework condition barrier is the limited opportunities for economic incentives. The most important subsidy scheme for households has been the rights-based national level economic support by the state-owned enterprise Enova. ${ }^{1}$ Household prosumers are guaranteed a refund of part of their investment costs (up to 2700 euro) through a standardised digital system, but this scheme is scheduled to end July 2021 as it is only meant to promote developments of new markets. In economic terms, recovery of costs of installations of solar household systems ranges from 10-15 years, because most of the household electricity consumed is not during the sunny parts of the year and because the tariff for selling excess produced electricity to the main grid is low (Standal, Talevi and Westskog, 2019). This excludes households that are not able to pay the up-front costs, and the existing regulations also exclude households that are not self-tenants in semi-detached or detached houses. It is worth noting that community energy is presented as an opportunity for citizens who lack the financial abilities or who live in apartment buildings to join citizen energy (GoN, 2021), but Enova does not operate with support for the category renewable energy communities. Instead, private entities can only apply for support in competition with commercial actors. Further, the projects must guarantee that they will be implemented regardless of whether they receive Enova support, which induces a high burden of responsibility on non-commercial actors. Some municipalities and grid companies have their own short term support schemes, but information is not as easily accessible and standardised as Enova's.

Although Norway has implemented both the plus customer scheme and the EU Energy Market Directive and included them in the newly released revised National budget 2021, renewable energy community, as defined in RED II (art. 2 ), is not on the policy agenda yet. Since Norway is not an EU member but only part of the European Economic Area (EEA) directives and EU policy does not automatically apply to Norway but depend on individual procedures and negotiations between the EU and the EEA/EFTA for each policy. It can take several years from the EU decision is made until it is included in the EEA agreement. For instance, the Third Energy Package was not included in the EEA agreement until 2017 and adopted by the Norwegian Parliament in April 2018. The RED 
II (Directive (EU), 2018/2001) is still under review by the EEA/EFTA. Norway is not part of the EU reporting obligation of National Energy and Climate Plans and makes separate plans for energy and climate (Standal et al., 2021).

There are no regulations that actively prohibit such forms of energy installation, though individualised metering and lack of economic incentives are an important barrier. But, as a consequence of not implementing the RED II yet, there are no plans for implementing an enabling framework (Art. 22) to promote and facilitate the development of renewable energy communities. As a minimum requirement, the RED II enabling framework would ensure that unjustified regulatory and administrative barriers to renewable energy communities are identified and removed; that participation is accessible to all consumers, including those in low-income or vulnerable households and that tools to facilitate access to finance and information are available. ${ }^{2}$

From the electricity sector stakeholder perspective, citizen-driven distributed energy systems in the electricity systems challenge the principle of cost-efficiency and shared responsibility for grid supply (Interviews S1-S7). In the Inderberg et al. (2020) study, all grid company interviewees were concerned with the technical requirements needed to connect prosumers to the grid and ensure phase-frequency stability. Further, the exemption from electricity fees and the extra costs for grid companies for securing integration entails that more costs are transferred to all customers (Standal et al., 2021). ${ }^{3}$ A result is that these costs are also shifted to those who do not have the ability to invest in household or community energy production. It also involves a radical conceptual break with the general understanding of solidarity in paying for grid supply (Standal et al., 2018). Several grid companies are, however, implementing their own pilot projects with storage and distributed energy systems to provide flexibility and better load management in their grid area. There are also examples of arrangement between prosumers and grid companies to provide flexibility. Recently, there has been attention towards measures for flexible electricity consumption as seasonal variations and peak-hour demands and new trends in household devices (e.g., electric vehicles) challenge grid capacity. NVE are currently developing a new grid tariff structure that will be capacity-based (NVE, 2019). Consumers that have a high energy consumption at times of peak load will be charged more. The suggestion has been met with opposition from companies selling PV systems for household prosumers as well as housing associations.

The technocratic narrative and shared understanding of electricity manifested in policy and regulations impact who are recognised as legitimate stakeholders. In general, the regulations are made with consumer rights in mind, but without addressing consumer differentiation in terms of gender and social class. The government and NVE thus still sees itself as a regulator and not a facilitator of an energy transition encompassing a range of actors participating on equal terms. There are no strong voices in policy arguing for economic incentives, and the tariff for selling surplus electricity is low. Renewable energy communities could also provide flexibility in the grid system as well as provide opportunities for local growth (grid expansion to rural areas is costly and falls on the commercial sector) 
(Standal et al., 2021). Still, the focus is on new grid tariffs and a continuation of the present system that privileges conventional players.

\section{The prosumer narrative: the educated, middle-class environmentalist with technological interest}

To fully understand how the dominating energy narrative reinforces and produce structures of gender and intersectional social differentiation, we draw on qualitative studies that have investigated the narratives of citizens who have engaged with energy production, including the interviews drawn on in this chapter (see also Standal, Talevi and Westskog, 2019). The narrative of prosumers in Norway is markedly different than the electricity system imaginary depicted above, where citizens partake as end-consumers and do not step into roles of electricity production and supply. Instead, their narrative depicts citizens who deeply engage with their electricity consumption and technology that enables this engagement; but the narratives also suggest that there are considerable transaction costs that exclude on the basis of economic capital, skills and networks (which are unevenly distributed in terms of class and gender). Further, this narrative reveals the different distribution of needs and interests between women and men in prosumerism.

The high up-front cost has probably been a major barrier for households, and in the Inderberg et al. study (2020), this was given as the main reason for households not investing in becoming prosumers. Further, transaction costs (e.g., handling solar companies, regulatory procedures and grid companies) were seen as another major hurdle, both by prosumers themselves, but also as a reason to not invest in solar PV (Inderberg et al., 2020; Standal, Talevi and Westskog, 2019).

Due to the limited economic incentives and policy commitments, the prosumers themselves have been the main driver for prosuming in Norway (Inderberg et al., 2020). The drivers for becoming prosumers were found to be environmental reasons; the prosumers interviewed wanted to contribute to the energy transition by using solar PV for their electricity consumption and to promote a market for prosumerism (Inderberg et al., 2020; Standal, Talevi and Westskog, 2019). Another main driver to become prosumers in Norway has been technological interest. In the interviews drawn upon in this study, more than half of the households worked in the energy sector (six men and two women) (Standal, Talevi and Westskog, 2019). Becoming prosumers was seen as means to get more experience with the technology out of professional or personal interest. Several of them also had reduced costs from the installation since either their employer had subsidised part of the equipment, or they could handle most of the installation on their own or with help from their network.

These findings correlate well with the dominating narrative of the general prosumer: middle-class, educated, environmentally conscious, techno-savvy person (Standal, Talevi and Westskog, 2019; Strenger, 2014). This imagined prosumer, very often attributed the male gender, was depicted by both the women and men interviewed. As described by a woman informant: "I picture a man, with at least four years education, or maybe self-taught, with an electric car. And politically 
oriented towards the left" (Interview with woman H9). In terms of gender, the reason given was that men were more interested in technology than women and, therefore, more enthusiastic to participate in the uptake of new domestic energy technology.

But there were also clear gender roles in the energy narratives of the prosumer households. In the Standal, Talevi and Westskog (2019) study, it was almost exclusively men who brought prosuming on the household agenda and who took care of the process concerning finding relevant information and dealing with the necessary vendors, grid companies and etc. Most of the women preferred leaving these tasks to their husbands as "this was his thing" and he had the knowhow and technological interest. Several women expressed that they did not feel comfortable or capable of dealing with finding the right information and communicating with suppliers and electricians. A notable exception was women working in the energy sector who had the needed social networks and particular knowledge in the field. In these households, women were the main initiators, and the investment was based on their decision. Despite women being reluctant to participate in the uptake of new energy technology in their homes, decisions to become prosumers were always stated to be taken jointly by the couple in line with Norwegian values of gender equality. Nevertheless, a few women felt they had "given in" to their partner's wish even though they initially had other priorities for the money being spent (Standal, Talevi and Westskog, 2019).

Even after the technology was implemented in the prosumer households interviewed, there were clear gender roles in the tasks performed. All the households interviewed in the study of Standal, Talevi and Westskog (2019) had taken a keener interest in their energy consumption after becoming prosumer and encouraged the other household members to shift their energy consumption to the daytime and days with sunny weather to consume most of the energy they produced (the price for selling excess electricity back to the grid is less than the price for consumption). But, it was mostly men who reported checking on the electricity production and consumption. Women, on the other hand, committed to change their household-chores practices by checking weather forecasts and doing laundry or vacuuming on sunny days to make the most of the energy they produced:

When I want to put the washing machine on, I check [electricity production] and if we're not producing enough, then I think OK, I'll wait a bit and see if it's sunny later. Or, I generally know if it will be good weather because I check the weather forecast.

(Interview H4)

Women who were more time-flexible during the day (e.g., housewives, retired or living on disability benefits) experienced this adaptation of their householdchores practices to be easier than women working outside the home. Studies find that women do most of the energy-related domestic work also in Western contexts (Standal, Winther and Danielsen, 2018; Bell et al., 2015). This reveals 
the different distribution of needs and interests between women and men in prosumerism. Women assume a higher burden of responsibility for changing energy practices (time of housework) while they felt less control of the decision-making and technology-implementation process to become prosumers. Despite women not being engaged in the "technicalities" of becoming prosumers, they did identify themselves with being prosumers when engaging with neighbours, friends and colleagues. This identification suggests that prosuming was important to these women.

Research has pointed out that community-driven renewable systems provide opportunities for women, unskilled and different class groups to participate in the energy transition and energy ownership (Standal and Feenstra, 2021). However, due to the lack of policy instruments and current regulations, Norwegian citizens who want to establish energy communities face an even higher threshold of meeting financial, human and social capital than household prosumers. Citizendriven community energy is still rare in the Norwegian context, with only a few low-voltage grids in farming communities, grid company pilots and housing collectives.

As shown, the citizen narrative depicted above reveals that even though prosuming provide a new energy narrative, the imagined prosumer reveals that the category is limited to men with the right capital and that becoming prosumers produced/reproduced a gendered division of labour in the household where men took care of the process of becoming prosumers, while women carried out most of the work to change their energy practices to optimise the gains of their solar PV investment.

\section{Discussion}

As shown above, the dominating narrative of Norway's electricity system and their materialisation in regulations are not well-aligned for a more demanddriven energy transition where there is a shift of power from traditional actors and towards large-scale citizen energy production in households or communities. This may compromise the needed energy transition as grassroots initiatives remain a niche that does not challenge the existing system (Seyfang et al., 2014). The regulators NVE have been preoccupied with removing regulatory barriers, but this is not the same as a policy agenda that promotes citizen energy production for all and address the social dimension of an inclusive energy transition. This is in contrast with the pressing policy concern to expand renewable electricity production (e.g., based on political ambitions of electrification of the transport sector) where onshore wind power was signalled as "a new resource." As an example, enabling onshore wind power-based energy communities before developing large wind power parks in nature landscapes could have increased social acceptance of renewables.

Exploring the energy narratives of the Norwegian electricity system reveals that there is a lack of momentum for citizen energy production, as well as addressing people's access and ability to participate in such a grassroot transition. Alternative narratives are marginalised due to the existence of abundant fully 
renewable electricity supply and the ideology of a cost-efficient rational energy system. When viewed through a justice lens, it becomes clear that there is a social differentiation in access to capital in terms of participating on equitable terms in the energy transition as a household or community energy producer. This relates to the politics of distribution (where certain men have more access to necessary material and immaterial capital). As shown, the problem becomes apparent in material and immaterial capital needed for engaging citizen energy production as such capital is unevenly produced. Further, women are underrepresented in STEM education and occupations in Norway (Statistics Norway, 2021b) and thus lack the human and social capital that have characterised the pioneers of Norwegian prosumers (Inderberg et al., 2020; Standal, Talevi and Westskog, 2019). As decarbonisation will entail a future increasingly reliant on new technological innovations and automatisation in the household sphere, there is a risk of increased social differentiation, including class, gender, age, as some have more capital to adapt to such a context. However, economic, human and social capital is not equally distributed among men either. In general, underrepresented groups are facing obstacles (e.g., financial capital, language barriers and housing types) to participate in the energy transition. This is perpetuated by the fact that energy communities often do not know how to approach marginalised groups in society, too (Guyet, Hanke and Feenstra, 2021).

Where the previous paragraphs demonstrate distributional and procedural injustices hindering participation of new prosumers in the Norwegian energy system, also recognitional injustices are observed (where women and marginalised groups' interest and needs are not recognised on equitable terms). Misrecognition can be understood as devaluation of certain activities based on (androcentric) norms and how this plays out in maldistribution:

To be misrecognized, accordingly, is not simply to be thought ill of, looked down upon or devalued in others' attitudes, beliefs or representations. It is rather to be denied the status of a full partner in social interaction, as a consequence of institutionalized patterns of cultural value that constitute one as comparatively unworthy of respect or esteem.

Fraser (2000, p. 113)

An important contribution of this chapter is also to show how inequalities concerning access to energy resources need to be understood in intersection with culture and discourse (Fraser, 2000). As demonstrated, women's lack of symbolic capital entailed that they did not see themselves confident to fully participate as prosumers. Those women among our respondents that took the initiative in their households to become prosumers were employed in the energy sector, hence feeling more capable to make energy-related decisions.

A more gender balanced employment in the energy sector (and STEM education) would likely have significance in women being recognised as legitimate and competent in all aspects of becoming a prosumer. However, as this chapter suggests, the subtle mechanisms of exclusion also matter, as prosumerism is unlikely 
to become mainstream if it only appeals to those that are understood as technically competent (e.g., Strenger, 2014). To overcome such "subordination," there is a need for increased recognition of underrepresented groups in society and a redistribution of power in the electricity system for other actors such as communities or households. A potential step would be to link energy policy more closely to other policy areas such as gender equality and preserving Sami livelihoods (in conjunction with the value of Indigenous knowledge and practices in addressing climate change issue).

Another potential step would be to secure framework conditions that promote the development of business models that lower the threshold for engaging in citizen energy production. In recent years, a few PV companies in Norway have developed business models that facilitate the entire process of becoming a household prosumer, which to some extent has been an intermediating factor in increasing the number of prosumers (Inderberg et al., 2020). Still, these companies are clustered around city areas and require high up-front costs and are thus only available to middle- or upper-class families who reside in urban areas. As a result, it is evident that without a justice perspective on the policy arena to provide an enabling framework, legal support and financial resources to overcome unequal access to citizen energy production, the participation level (including currently underrepresented groups) will not change (Guyet, Hanke and Feenstra, 2021). European policy, like RED II, stimulates local energy initiatives to contribute to just transitions and access to clean energy for all Europeans. However, as demonstrated in the Norwegian profile, if the national government is not obliged to report the process of implementation to the European Commission, the progress of creating and enforcing a policy agenda might be slow.

\section{Conclusion}

This chapter contributes to deepening the understanding of prosumers as emerging actors in the energy transition by demonstrating the narratives of the Norwegian electricity system and identifying the obstacles and opportunities for women and men to become prosumer. We engaged with the energy justice literature and explained inequalities in the light of capital approaches. Norway provides a distinct context concerning engaging citizens as energy producers. There is a strong emphasis on the reliable, cost-efficient energy system, and the momentum for change is weak since the energy production and supply is almost entirely renewable, cost efficient, and the dividend is distributed to the population. Increasing the share of prosumers and renewable energy communities is therefore almost absent among the public and the policy agenda. Since Norway is not an EU member, RED II is also not being transposed or implemented in line with the EU Member States. The result is that citizen energy production constitutes a "niche" market in the electricity system. Since there are no real economic incentives and the transaction costs are high for citizens, it requires a high degree of economic, human and social capital of individuals to engage with prosumerism. In sum, the outcome is that though there is a growing interest in distributed energy systems 
among traditional electricity sector actors (e.g., grid companies) or "big players" such as property owners, the scale-up grassroot citizen energy production is going slow (Standal et al., 2021). When looking beyond the material structural factors that limit the access to become energy producers, we find more finetuned nuances where certain groups of people are inhibited from full participation. This misrecognition in energy participation has roots in cultural norms that value certain activities and attributed identities over others. Even though the Nordic countries are considered having high gender equality in society, this Norwegian case study observed gender inequalities in engaging in prosumerism and the uptake of domestic renewable energy technologies due to social gender roles and relations that result in social differentiation in access to relevant human, social and symbolic capital. This is revealed in the perceived "lack of interest for technology" attributed to women and the produced lack of self-confidence to be knowledgeable enough to participate in the uptake of new energy technology. However, more empirical research is needed to analyse whether all underrepresented groups are experiencing the same challenges and whether these gendered differences are decreasing as policies, regulations and commercial actors take a more facilitating role towards citizen energy production. Insights in how policy interventions can facilitate and stimulate participation in renewable energy initiatives could contribute to furthering just transitions.

\section{Notes}

1 In 2019, Enova provided of 5.6 billion NOK (520 million euro) to energy and climate projects (Standal et al. 2021).

2 Article 22 (4) of RED II includes several more requirements. For more information see Standal et al. (2021, p. 9).

3 In Norway, households are both customers to grid companies (under regulated monopoly) and power production companies and they pay both for the use of the transmission grid and for the amount of electricity consumed.

\section{References}

Ahlborg, H. (2017) 'Towards a conceptualisation of power in energy transitions', Environmental Innovation and Societal Transitions, 25, Amsterdam: Elsevier, pp. 122-41.

Allen, E., Lyons, H. and Stephens, J. C. (2019) 'Women's leadership in renewable transformation, energy justice and energy democracy: Redistributing power', Energy Research and Social Science, 57, Amsterdam: Elsevier, pp. 1-11.

Bell, S., Judson, E., Bulkeley, H., Powells, G., Capova, K. and Lynch, D. (2015) 'Sociality and electricity in the United Kingdom: The influence of household dynamics on everyday consumption', Energy Research and Social Science, 9, Amsterdam: Elsevier, pp. 98-106.

Bourdieu, P. (1986) 'The forms of capital', in J. Richardson (ed.), Handbook of theory and research for the sociology of education. New York: Greenwood, pp. 241-58.

Bredvold, T. L. (2020) Where no one is poor, and energy is abundant: A study of energy poverty in Norwegian households. MA dissertation, University of Oslo. Online: https://www.duo 


\section{2}

.uio.no/bitstream/handle/10852/80221/1/masters-thesis-Torjus-Lunder-Bredvold.pdf (Accessed on 2021-06-25).

Breitschopf, B., Grave, K. and Bourgault, C. (2016) Electricity costs of energy-intensive industries in Norway - A comparison with energy-intensive industries in selected countries. Report for Energy Norway. Online: https://www.energinorge.no/contentassets/525 e77b1feff4203a94ef6d1f94cfd03/electricity-costs-of-energy-intensive-industries-in -norway.pdf (Accessed on 2021-06-25).

Clancy, J. and Feenstra, M. H. (2019) Women, gender equality and the energy transition in the EU. Study for the FEMM Committee of the EU Parliament, PE 608.867. Brussels: EU.

Diestelmeier, L. and Hesselman, M. (2018) 'The position of the household consumer in the EU winter package: Between participation and protection', Nederlands Tijdschrift voor Energierecht, 17(1,2), pp. 31-40, Deventer: Den Hollander.

Ellegård, K. and Palm, J. (2015) 'Who is behaving? Consequences for energy policy of concept confusion', Energies, 8(8), Basel: MDPI, pp. 7618-37. DOI:10.3390/ en 8087618

Feenstra, M. and Clancy, J. (2020) 'A view from the North: Gender and energy poverty in the European Union', in Clancy, J., Özerol, G., Mohlakoana, N., Feenstra, M. and Sol Cueva, L. (eds.), Engendering the energy transition. Cham: Palgrave Macmillan, pp. 163-187. DOI:10.1007/978-3-030-43513-4_8

Feenstra, M. and Özerol, G. (2021) 'Energy justice as a search light for gender-energy nexus: Towards a conceptual framework', Renewable and Sustainable Energy Reviews, 138(110668), pp. 1-11, Amsterdam: Elsevier.

Fraser, N. (2000) 'Rethinking recognition', New Left Review, 3, London: New Left Review Ltd., pp. 107-20.

Fraser, N., Dahl, H. M., Stoltz, P. and Willig, R. (2004) 'Recognition, redistribution and representation in capitalist global society: An interview with Nancy Fraser', Acta Sociologica, 47(4), Thousand Oaks: SAGE Publishing, pp. 374-82.

Fraune, C. (2015) 'Gender matters: Women, renewable energy, and citizen participation in Germany', Energy Research and Social Science, 7, Amsterdam: Elsevier, pp. 55-65.

GoN (2016) Meld. St. 25 (2015-2016). Power for change: Energy policy towards 2030 (author's translation from Norwegian). White paper from the Norwegian Ministry of Petroleum and Energy, Oslo: Norwegian Ministry of Petroleum and Energy.

GoN (2021) Meld. St. 2 (2020-2021). Revised national budget. White paper from the Norwegian Ministry of Finance, Oslo: Norwegian Ministry of Finance.

Guyet, R., Hanke, F. and Feenstra, M. (2021) 'Energy communities and energy poverty: Moving towards a new social and ecological contract', ENGAGER Policy Brief Working Group 4, No. 3. Online: http://www.engager-energy.net/wp-content/uploads/2021/03/ WG4-policy-brief-March-31.pdf (Accessed on 2021-25-06).

Holden, E., Banister, D., Gossling, S., Linnerud, K. and Gilpin, G. (2020) 'Grand narratives of sustainable mobility: A conceptual review', Energy Research and Social Science, 65, Amsterdam: Elsevier, pp. 2-10.

Holden, E., Linnerud, K. and Rygg, B. J. (2021) 'A review of dominant sustainable energy narratives', Renewable and Sustainable Energy Reviews, 144, Amsterdam: Elsevier, pp. 1-11.

Inderberg, T. H., Sæle, H., Westskog, H. and Winther, T. (2020) 'The dynamics of solar prosuming: Exploring interconnections between actor groups in Norway', Energy Research and Social Science, 70, Amsterdam: Elsevier, pp. 1-11. 
Inderberg, T. H., Tews, K. and Turner, B. (2018) 'Is there a prosumer pathway? Exploring household solar energy development in Germany, Norway, and the United Kingdom', Energy Research and Social Science, 42, Amsterdam: Elsevier, pp. 258-69.

Jenkins, K., McCauley, D., Heffron, R., Stephan, H. and Rehner, R. (2016) 'Energy justice: A conceptual review', Energy Research and Social Science, 11, Amsterdam: Elsevier, pp. 174-82.

Jensen, E. S. and Aamodt, S. (2020) D5 .2. Case study report on governance barriers to energy transition: Country report Norway. ENABLE EU report.

Johnson, O. W., Han, J. Y., Knight, A., Mortensen, S., Thazin, M., Boyland, M. and Resurrección, B. P. (2020) 'Intersectionality and energy transitions: A review of gender, social equity and low-carbon energy', Energy Research and Social Science, 70, Amsterdam: Elsevier, pp. 1-11.

Juntunen, J. K. (2014) 'Domestication pathways of small-scale renewable energy technologies', Sustainability: Science, Practice and Policy, 10(2), Abingdon: Taylor \& Francis, pp. 28-42.

Leiren, M. D., Aakre, S., Linnerud, K., Julsrud, T. E., Di Nucci, M. R. and Krug, M. (2020) 'Community acceptance of wind energy developments: Experience from wind energy scarce regions in Europe', Sustainability, 12(5), Basel: MDPI, p. 1754.

Lieu, J., Sorman, A. H., Johnson, O. W., Virla, L. D. and Resurrección, B. P. (2020) 'Three sides to every story: Gender perspectives in energy transition pathways in Canada, Kenya and Spain', Energy Research and Social Science, 60, Amsterdam: Elsevier, pp. 1-12.

Linnerud, K., Aakre, S. and Leiren, M. D. (2018) Technical and socio-economic conditions: A literature review of social acceptance of wind energy development, and an overview of the technical, socio-economic and regulatory starting conditions in the wind energy scarce target regions. WinWind Report. Online: https://winwind-project.eu/fileadmin/user_upload/ Resources/Deliverables/Del2.1_final.pdf (Accessed on 2021-06-25).

Linnerud, K., Toney, P., Simonsen, M. and Holden, E. (2019) 'Does change in ownership affect community attitudes toward renewable energy projects? Evidence of a status quo bias', Energy Policy, 131, Amsterdam: Elsevier, pp. 1-8.

McCauley, D., Heffron, R. J., Stephan, H. and Jenkins, K. (2013) 'Advancing energy justice: The triumvirate of tenets and systems thinking', International Energy Law Review, 32(3), London: Sweet \& Maxwell, pp. 107-10.

NVE (2019) 'Summary of consultation and recommendations to changes in the grid tariff structure' [Oppsummering av høring og anbefaling til endringer i nettleiestrukturen]. REM rapport 6/2019.

NVE (2021) 'Ownership in Norwegian hydro and windpower (authors' translation)'. Online: https://www.nve.no/energiforsyning/kraftmarkedsdata-og-analyser/eierskap-i -norsk-vann-og-vindkraft/?ref=mainmenu (Accessed on 2021-06-25).

Olivier, D. F., Marulli, D. E. and Fonteneau, R. (2017) 'Foreseeing new control challenges in electricity prosumer communities', in: IREP Symp. Power Syst. Dyn. Control X, Espinho, Portugal. Espinho: IREP.

Olkkonen, L., Korjonen-Kuusipuro, K. and Grönberg, I. (2017) 'Redefining a stakeholder relation: Finnish energy 'prosumers' as co-producers', Environmental Innovation and Societal Transitions, 24, Amsterdam: Elsevier, pp. 57-66.

Palm, J. (2018) 'Household installation of solar panels: Motives and barriers in a 10-year perspective', Energy Policy, 113, Amsterdam: Elsevier, pp. 1-8.

Parag, Y. and Sovacool, B. K. (2016) 'Electricity market design for the prosumer era', Nature Energy, 1, London: Nature Research, p. 16032. 


\section{Karina Standal and Mariëlle Feenstra}

Schleicher-Tappeser, R. (2012) 'How renewables will change electricity markets in the next five years', Energy Policy, 48, Amsterdam: Elsevier, pp. 64-75.

Seyfang, G., Hielscher, S., Hargreaves, T., Martiskainen, M. and Smith, A. (2014) 'A grassroots sustainable energy niche? Reflections on community energy in the UK', Environmental Innovation and Societal Transitions, 13, Amsterdam: Elsevier, pp. 21-44.

Skjølsvold, T. M., Throndsen, W., Ryghaug, M., Fjellså, I. F. and Koksvik, G. H. (2018) 'Orchestrating households as collectives of participation in the distributed energy transition: New empirical and conceptual insights', Energy Research and Social Science, 46, Amsterdam: Elsevier, pp. 252-61.

Sovacool, B. and Dworkin, M. (2015) 'Energy justice: Conceptual insights and practical applications', Applied Energy, 142, Amsterdam: Elsevier, pp. 435-44.

Sovacool, B., Heffron, R., McCauley, D. and Goldthau, A. (2016) 'Energy decisions reframed as justice and ethical concerns', Nature Energy, 1(5), London: Nature Research, p. 16024.

Standal, K., Aakre, S., Alonso, I., Azevedo, I., Bastiani, M., del Bufalo, N., Caliano, M., Delvaux, S., Di Nucci, R., Fouquet, D., Gatta, V., Gimenez, X., Klāvs, G., Krug, M., Kudrenickis, I., Laes, E., Linnerud, K., De Luca, E., Maleki, P., Meynaerts, E., Nowakowski, P., Oteri MG., Pappa, S., Schumann, R., Vansintjan, D., Venerucci, V., Wnuk, R., Zučika, A. and Aamodt, S. (2021) D2.1 assessment report on technical, legal, institutional and policy conditions in the COME RES countries. Online: https://come-res .eu/fileadmin/user_upload/Resources/Deliverables/COME_RES_D2.1__Assessment _report_FINAL.pdf (Accessed on 2021-06-25).

Standal, K. and Feenstra, M. (2021) 'Women and solar energy in a global energy transition', in Webb, J., Tingey, M. and Wade, F. (eds.), Handbook of energy and society. Cheltenham: Edward Elgar Publishing, pp. 142-154.

Standal, K., Talevi, M. and Westskog, H. (2019) 'Engaging men and women in energy production in Norway and United Kingdom: The significance of social practices and gender relations', Energy Research and Social Science, 60(101338), Amsterdam: Elsevier, pp. 1-9.

Standal, K., Westskog, H., van Kraalingen, I., Paolucci, L., Reljic, M., Talevi, M. and Chubyk, A. (2018) Synthesis report: «From consumer to prosumer», ENABLE.EU D4.3 report, October 2018.

Standal, K., Winther, T. and Danielsen, K. (2018) 'Energy politics and gender', in Hancock, K. and Allison, J. (eds.), Oxford handbook of energy politics. Oxford: Oxford University Press, pp. 197-216..

Statistics Norway (2021a) 'Windpower is increasing (authors' translation)'. Online: https://www.ssb.no/energi-og-industri/artikler-og-publikasjoner/vindkraften-fortsetter -a-stige (Accessed on 2021-06-25).

Statistics Norway (2021b) 'Occupation register'. Online: https://www.ssb.no/statbank/list /regsys/ (Accessed on 2021-06-25).

Strenger, Y. (2014) 'Smart energy in everyday life: Are you designing for resource man?', Interactions, 21(4), New York: ACM, pp. 24-31.

Wethal, U. (2020) 'Practices, provision and protest: Power outages in rural Norwegian households', Energy Research $\mathcal{G}$ Social Science, 62, Amsterdam: Elsevier, pp. 1-11.

Winther, T., Westskog, H. and Sæle, H. (2018) 'Like having an electric car on the roof: Domestication PV solar panels in Norway', Energy for Sustainable Development, 47, Amsterdam: Elsevier, pp. 84-93. 